\title{
ANALISIS PENGARUH PENGUNGKAPAN CORPORATE SOCIAL RESPONSIBILITY DAN KINERJA KEUANGAN TERHADAP FIRM VALUE PADA INDEKS SAHAM LQ 45 YANG TERDAFTAR DI BEI
}

\section{EFFECT ANALYSIS OF CORPORATE SOCIAL RESPONSIBILITY DISCLOSURE AND FINANCIAL PERFORMANCE TO FIRM VALUE ON STOCK INDEX LQ 45 REGISTERED IN IDX}

\author{
Oleh: \\ Jovita Marcella \\ Universitas Pelita Harapan \\ Jovita.marcella@yahoo.com \\ 081286526377 \\ Wijaya Triwacananingrum \\ Universitas Pelita Harapan \\ Wijaya.tri@uph.edu \\ 08123034093
}

\begin{abstract}
Abstrak
Penelitian ini bertujuan untuk mengetahui pengaruh pengungkapan Corporate Social Responsibility (CSR) dan kinerja keuangan terhadap firm value perusahaan. Populasi dalam penelitian ini adalah perusahaan LQ 45 yang terdaftar di BEI periode 2012-2016. Teknik pengambilan sampel dilakukan dengan metode purposive sampling dan berdasarkan kriteria yang telah ditentukan maka jumlah sampel yang diperoleh dalam penelitian adalah sebanyak 110 sampel perusahaan LQ 45 yang berturutturut melaporkan laporan keuangan dengan lengkap serta menerapkan praktik CSR selama periode 2012-2016. Hasil penelitian ini membuktikan bahwa secara parsial profitabilitas (ROA) dan leverage (DR) perusahaan berpengaruh signifikan terhadap nilai perusahaan, jadi kondisi kinerja keuangan perusahaan berpengaruh terhadap minat investor dalam berinvestasi dan ketika debt ratio meningkat maka nilai perusahaan juga meningkat. Sedangkan pengungkapan CSR dan likuiditas (CR) perusahaan secara parsial tidak berpengaruh signifikan terhadap nilai perusahaan. Namun , jika dilihat secara bersamaan keduanya pengungkapan CSR dan kinerja keuangan memiliki pengaruh signifikan terhadap nilai perusahaan.
\end{abstract}

Kata kunci : Corporate Social Responsibility, Return On Asset, Current Ratio, Debt Ratio dan Price to Book Value

\footnotetext{
Abstract

This study aims to determine the influence of disclosure of Corporate Social Responsibility (CSR) and financial performance to the firm's value. The population in this research is $L Q 45$ company listed in BEI during the period of 2012-2016. The sampling technique was done by purposive sampling method and based on predetermined criteria, the number of samples obtained in the research were 110 samples of $L Q 45$ companies that reported the complete financial report and applied CSR practice for the period 2012-2016. The results of this study prove that partial profitability (ROA) and leverage (DR) companies have a significant effect on the value of the company, so the condition of the company's financial performance influence the investor interest in investing and when the debt ratio increases then the value of the company also increases. While partial disclosure of CSR and liquidity $(C R)$ of the company provides no significant effect on the value of the company. However, when viewed simultaneously, both CSR disclosures and financial performance have a significant influence on the firm's value.
} 
Keywords: Corporate Social Responsibility, Return On Asset, Current Ratio, Debt Ratio and Price to Book Value

\section{PENDAHULUAN}

\section{Latar Belakang}

Sejalan dengan perkembangan perekonomian, banyak perusahaan yang melakukan ekspansi usaha. Pemenuhan kebutuhan dana perusahaan dapat diperoleh dengan melakukan pinjaman dalam bentuk hutang atau dengan menerbitkan saham di pasar modal. Perusahaan yang menerbitkan saham di pasar modal atau go public berarti bahwa kepemilikan perusahaan sudah bukan menjadi pemilik yang mendirikan perusahaan itu saja, melainkan juga menjadi milik masyarakat yang ingin membeli saham perusahaan tersebut (Dwipayana dan Suaryana 2016).

Menurut Hartono (2010) dalam Dwipayana dan Suaryana (2016) terdapat tiga jenis nilai saham yang terdiri atas nilai buku, merupakan nilai saham menurut pembukuan emiten; sedangkan nilai pasar, merupakan pembukuan nilai di pasar saham dan terakhir nilai intrinsik, merupakan nilai yang sebenarnya dari saham. Salah satu pendekatan dalam menentukan nilai intrinsik saham adalah Price to Book Value (PBV). Investor perlu memahami ketiga nilai tersebut sebagai informasi penting dalam mengambil keputusan. Nilai perusahaan yang tinggi menjadi keinginan para pemilik perusahaan, sebab dengan nilai yang tinggi menunjukkan kemakmuran pemegang saham juga tinggi. Investor juga cenderung lebih tertarik menanamkan sahamnya pada perusahaan yang memiliki kinerja baik dalam meningkatkan nilai perusahaan.

Naik turunnya harga saham di pasar modal menjadi sebuah fenomena yang menarik untuk dibicarakan berkaitan dengan isu naik turunnya nilai perusahaan itu sendiri. Kondisi tersebut secara tidak langsung akan mempengaruhi nilai perusahaan. Oleh sebab itulah berbagai cara ditempuh perusahaan-perusahaan untuk meningkatkan value dari masing-masing perusahaan agar dapat survive untuk mempertahankan nilai dari perusahaannya sendiri serta bersaing dengan perusahaan lainnya. Tren yang saat ini sedang berkembang pada dunia bisnis adalah dengan penerapan green investment. Tren ini merupakan tren positif yang sekarang ini perlu dipertimbangkan oleh perusahaan dalam upaya meningkatkan nilai perusahaan serta sekaligus dapat menjaga keberlangsungan life cycle dari masingmasing perusahaan sampai jangka panjang agar generasi selanjutnya akan terus dapat menikmati sumber daya sama dengan kita saat ini (William, 2012).

Banyaknya perusahaan yang hanya berfokus kepada pertumbuhan ekonomi menyebabkan banyak perusahaan di Indonesia menghadapi gugatan dari masyarakat sekitar karena menyebabkan masalah-masalah seperti limbah, polusi, rusaknya lingkungan, hak dan status pekerja. Sebagai salah satu bukti nyata di Papua, PT Freeport mengabaikan kehidupan masyarakat yang hidup miskin dan nyaris tak tersentuh perhatian perusahaan. Bahkan berbagai tindakan anarkis ditimpakan kepada mereka saat mengais sisa produksi di areal pembuangan limbah. Oleh karena itu, green investment dapat menjadi strategi baru perusahaan dengan cara mengaplikasikan program corporate social responsibility (CSR) untuk membangun hubungan antara perusahaan dengan stakeholders. Dengan adanya pelaksanaan CSR ini diharapkan para stakeholder memiliki pandangan positif terhadap perusahaan dan mengundang investor untuk menanamkan modal pada perusahaan. CSR sering dianggap inti dari etika bisnis, yang berarti bahwa perusahaan tidak hanya mempunyai kewajibankewajiban ekonomi dan legal (artinya kepada pemegang saham atau shareholder) tetapi juga kewajiban-kewajiban terhadap pihak-pihak lain yang berkepentingan (stakeholder) yang jangkauannya melebihi kewajiban kewajiban ekonomi dan legal 
(Kusumadilaga, 2010). Inti dari pengungkapan informasi financial dan nonfinancial ini adalah menciptakan citra perusahaan yang mampu menjadi strategi perusahaan untuk menarik minat stakeholder termasuk shareholder untuk turut mengambil bagian dalam menanamkan modal, maupun bekerjasama dengan perusahaan. Oleh karena itu penting bagi para perusahaan untuk memberi sinyal kepada stakeholder mengenai pemenuhan tanggung jawab perusahaan secara sosial, maupun menyajikan informasi keuangan yang dapat dipahami, relevan dan dapat dibandingkan agar para stakeholder memiliki pandangan positif terhadap sinyal yang diberikan oleh perusahaan sehingga dapat meningkatkan nilai perusahaan (Ariella, 2015).

Berdasarkan latar belakang permasalahan yang telah diuraikan, maka penulis tertarik untuk membahas topik ini dan menguji hipotesis yang berkaitan dengan pengungkapan CSR dan kinerja keuangan pada indeks saham LQ 45 untuk melihat serta membandingkan apakah indeks saham LQ 45 yang secara kriteria BEI memiliki indeks saham yang baik ini dipengaruhi nilai sahamnya tidak hanya berdasar faktor financial saja namun juga berdasar faktor non financial berupa CSR.

\section{Teori Pemangku Kepentigan (Stakeholder Theory)}

Berdasarkan asumsi stakeholder teori, maka perusahaan tidak dapat melepaskan diri dari lingkungan sosial. Perusahaan perlu menjaga legitimasi stakeholder serta mendudukkannya dalam kerangka kebijakan dan pengambilan keputusan, sehingga dapat mendukung pencapaian tujuan perusahaan, yaitu stabilitas usaha dan jaminan going concern (Adam, dalam Nor Hadi, 2011).

\section{Teori Sinyal (Signaling Theory)}

Menurut Brocket (2012) dalam Sophia (2015), transparasi dan informasi yang berkualitas yang mencerminkan keberlanjutan dari suatu perusahaan adalah "darah" bagi pasar modal. Karena efisiensi pasar bergantung pada informasi tersebut, yang memampukan pasar untuk bertindak sebagai pemberi sinyal untuk alokasi modal.

Teori sinyal membahas mengenai dorongan perusahaan untuk memberikan informasi kepada pihak eksternal. Dorongan tersebut disebabkan oleh terjadinya asimetri informasi antara pihak manajemen (internal) dan pihak eksternal. Insiders hanya akan membeli saham apabila mereka tahu harga jual sekarang berada di bawah harga jual yang sebenarnya dan juga sebaliknya, insiders akan melakukan transaksi penjualan apabila mereka tahu harga jual sekarang berada di posisi premium. Salah satu informasi yang wajib untuk diungkapkan oleh perusahaan adalah informasi tentang tanggungjawab sosial perusahaan atau corporate social responsibility. Informasi ini dapat dimuat dalam laporan tahunan perusahaan atau laporan sosial perusahaan terpisah. Perusahaan melakukan pengungkapan CSR selain dengan merupakan upaya signaling kepada external shareholders juga dengan harapan dapat meningkatkan reputasi dan nilai perusahaan (Rustiarini,2010).

\section{Corporate Social Responsibility (CSR)}

CSR adalah sebuah etika yang memberikan sugesti pada perusahaan bahwa perusahaan, tidak memandang tipe dan ukuran perusahaan memiliki kewajiban untuk melindungi lingkungan di sekitar perusahaan beroperasi. Di dalam buku Corporate Sustainability: Integrating Performance and Reporting, Brocket (2012), mengutip pernyataan Rosabeth Moss Kanter yang menyatakan bahwa perusahaan perlu menganggap CSR sebagai sebuah pandangan yang lebih luas terhadap lingkungan dalam setiap aspek operasi, dan mengggunakannya sebagai strategi bisnis. Begitulah caranya perusahaan mampu mendapatkan kesempatan untuk bertumbuh dan berinovasi yang selalu berasal dari 
kebutuhan pasar yang tidak terpenuhi dan masalah yang belum terpecahkan.

Sedangkan jika melihat dari segi hukum Indonesia, pengertian CSR ini dapat ditemukan dalam pasal 1 ayat (3) UndangUndang Nomor 40 tahun 2007 tentang Perseroan Terbatas, "Tanggung jawab sosial dan lingkungan adalah komitmen Perseroan untuk berperan serta dalam pembangunan ekonomi berkelanjutan guna meningkatkan kualitas kehidupan dan lingkungan yang bermanfaat, baik bagi Perseroan sendiri, komunitas setempat, maupun masyarakat pada umumnya."

\section{Mengukur Kinerja Keuangan dengan Rasio Keuangan}

Tujuan utama menganalisa laporan keuangan adalah untuk mengidentifikasikan perubahan utama dalam trend, jumlah dan hubungan dan menginvestigasi alasan dari perubahan-perubahan tersebut. Seringkali, perubahan tersebut adalah sebuah sinyal untuk memperingatkan pergantian yang signifikan dari kesuksesan atau kegagalan suatu bisnis. Semakin tinggi kinerja keuangan, biasanya diproksikan dengan rasio keuangan, maka semakin tinggi pula nilai perusahaan. Melalui rasio-rasio keuangan tersebut dapat dilihat seberapa berhasilnya manajemen perusahaan mengelola asset dan modal yang dimilikinya untuk memaksimalkan nilai perusahaan (Gibson, 2011). Dan hasil dari perhitungan rasio digunakan baik untuk keperluan internal (manajemen perusahaan) maupun eksternal (pemegang saham, pemasok, pembeli, pemerintah termasuk pajak dan BPS, kreditur, investor, karyawan dll).

\section{Pengertian Firm Value/Nilai perusahaan}

Nilai perusahaan diartikan sebagai gambaran hasil kinerja perusahaan berupa keuntungan yang diraih perusahaan dalam suatu periode yang dilakukan oleh manajemen dengan mengelola asset dan kekayaan yang dimiliki perusahaan (Rahayu, 2010). Nilai perusahaan merupakan persepsi investor terhadap perusahaan, yang sering dikaitkan dengan harga saham. Harga saham yang tinggi membuat nilai perusahaan juga tinggi.

Wirawati (2008) mengemukakan bahwa PBV merupakan rasio untuk menentukan nilai intrinsik saham, yang akan mempengaruhi keputusan investor untuk membeli atau menjual saham. PBV menunjukkan seberapa jauh suatu perusahaan mampu menciptakan nilai perusahaan yang relatif terhadap jumlah modal yang diinvestasikan. Perusahaan yang memiliki rasio PBV yang meningkat dari tahun ke tahun berarti perusahaan tersebut berhasil menciptakan dan meningkatkan nilai perusahaan. Semakin tinggi rasio PBV dapat diartikan semakin tinggi suatu perusahaan dinilai oleh para investor dibandingkan dengan dana yang telah ditanamkan di perusahaan. Secara umum, kekayaan pemegang saham akan meningkat apabila harga saham perusahaan meningkat. Nilai perusahaan yang tinggi juga akan membuat investor percaya tidak hanya pada kinerja perusahaan saat ini namun juga pada prospek perusahaan masa datang. Dalam penelitian ini, nilai perusahaan diukur dengan Price to Book Value (PBV).

\section{Kerangka Konseptual}

Kerangka pemikiran ini terdiri dari variabel independen yaitu pengungkapan CSR dan kinerja keuangan yang diukur dengan tiga macam rasio yaitu rasio profitabilitas, rasio likuiditas dan leverage. Variabel dependen dari penelitian ini adalah nilai perusahaan atau firm value (PBV). Berikut gambaran pemikiran dari penelitian ini: 


\section{Non-Financial Performance}

X1: Pengungkapan

Corporate Social

Responsibility (CSR)

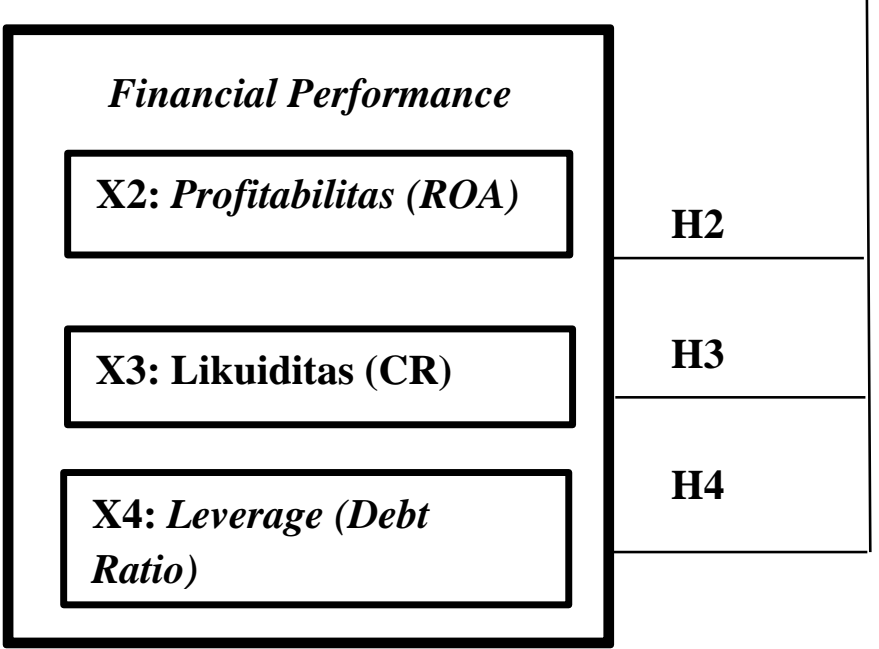

Independen Variabel
H1

Y:

Firm Value

(PBV)

\section{Gambar 2. Kerangka Konseptual}

\section{Pengaruh Pengungkapan CSR dengan}

Firm Value

Dengan perkembangan akhir-akhir ini banyak pihak yang memiliki kepentingan terhadap perusahaan yaitu stakeholders (konsumen, masyarakat, pemasok, analis keuangan, karyawan dan pemerintah). Stakeholders menyadari bahwa adanya hal yang dapat menambah nilai suatu perusahaan. Salah satu caranya dengan melakukan kegiataan yang berhubungan dengan aktivitas sosial

Menurut William pengungkapan CSR baik dimensi ekonomi, lingkungan, sosial, hak asasi manusia, masyarakat atau tanggung jawab produk berdasarkan GRI dapat dijadikan sebagai sinyal dari manajemen kepada seluruh stakeholder termasuk investor mengenai prospek perusahaan di masa yang akan datang bahwa perusahaan memberikan sinyal positif atas keberlangsungan hidup perusahaan di masa datang. Sinyal tersebut berusaha menginformasikan bahwa perusahaan tersebut lebih bernilai daripada perusahaan lain karena kepeduliannya terhadap dampak ekonomi, lingkungan dan sosial yang terwujud melalui aktivitas perusahaan. Berdasarkan hal tersebut maka 
hipotesis yang diajukan dalam penelitian ini adalah sebagai berikut:

H1: Pengungkapan corporate social responsibility (CSR) memiliki pengaruh positif dan signifikan terhadap firm value.

\section{Pengaruh Profitabilitas dengan Firm Value}

Husnan dan Pudjiastuti (2004) dalam Suaryana dan Dwipayana (2016) menyebutkan bahwa ROA adalah rasio untuk mengukur kemampuan aktiva perusahaan dalam memperoleh laba dari operasi perusahaan. ROA menunjukkan kemampuan perusahaan dalam menghasilkan laba dalam memanfaatkan total aset yang dimiliki perusahaan. Laba dapat mempengaruhi minat investor karena perusahaan yang berhasil akan menghasilkan laba yang stabil. Dengan laba yang tinggi maka tingkat kepercayaan investor juga akan meningkat dan hal tersebut akan berdampak pada PBV yang meningkat. Menurut Hakim dan Kundiman (2016) serta Wiksuana dan Pratama (2016) ROA memiliki pengaruh yang positif signifikan terhadap nilai perusahaan. Berdasarkan hal tersebut maka hipotesis yang diajukan dalam penelitian ini adalah sebagai berikut:

H2: Profitabilitas perusahaan yang diukur dengan ROA memiliki pengaruh positif dan signifikan terhadap firm value.

\section{Pengaruh Likuiditas dengan Firm Value Current Ratio (CR) yaitu} kemampuan aktiva lancar perusahaan dalam memenuhi kewajiban jangka pendek dengan aktiva lancar yang dimiliki. Jika current ratio baik maka kemampuan perusahaan akan semakin baik dalam mencukupi hutang jangka pendeknya dan terhindar dari masalah likuiditas. Oleh sebab itu, current ratio seharusnya cukup penting dipertimbangkan oleh para investor, karena liquidity ratio mengukur kecukupan sumber kas perusahaan untuk memenuhi kewajiban yang berkaitan dengan kas dalam jangka pendek. Semakin likuid perusahaan, maka semakin tinggi tingkat kepercayaan kreditur dalam memberikan dananya sehingga dapat meningkatkan nilai perusahaan di mata kreditur maupun calon investor. Berdasarkan hal tersebut maka hipotesis yang diajukan dalam penelitian ini adalah sebagai berikut:

H3: Likuiditas perusahaan yang diukur dengan current ratio memiliki pengaruh positif dan signifikan terhadap firm value.

\section{Pengaruh Leverage dengan Firm Value}

Menurut Prasetyorini (2013) dalam Pratama dan Wiksuana (2016) mengatakan bahwa leverage merupakan kebijakan pendanaan (external financing) yang berkaitan dengan keputusan perusahaan dalam membiayai perusahaan. Debt to Asset Ratio merupakan salah satu rasio yang termasuk dalam leverage. Rasio DR menunjukkan seberapa besar jumlah aktiva perusahaan yang dibiayai dengan total hutang yang dimiliki perusahaan. Rasio ini menekankan pentingnya pendanaan hutang dengan jalan menunjukkan persentase aktiva perusahaan yang didukung oleh hutang. Semakin tinggi DR berarti semakin besar jumlah modal yang digunakan sebagai modal investasi sehingga PBV meningkat. Berdasarkan hal tersebut maka hipotesis yang diajukan dalam penelitian ini adalah sebagai berikut:

$\mathrm{H} 4$ : Leverage perusahaan yang diukur dengan debt ratio memiliki pengaruh positif dan signifikan terhadap firm value.

\section{METODE PENELITIAN \\ Populasi dan Sampel}

Populasi dalam penelitian ini adalah seluruh perusahaan LQ 45 yang terdaftar di Bursa Efek Indonesia sebanyak 45 perusahaan. Sampel yang dipilih adalah perusahaan LQ 45 yang memiliki laporan 
tahunan lengkap dan memiliki informasi mengenai kegiatan CSR periode 2012-2016.

Teknik sampling yang dilakukan pada penelitian ini dengan menggunakan metode purposive sampling. Dimana sampel ditentukan berdasar kriteria dan karakteristik tertentu.

Berdasarkan kriteria, diketahui bahwa sampel yang didapat berdasarkan teknik purposive sampling adalah sebanyak 22 perusahaan dikarenakan terdapat 23 perusahaan yang tidak memenuhi kriteria sampel penelitian. Sehingga jumlah sampel untuk penelitian ini selama 5 tahun sebanyak 110.

\section{Model Empiris Penelitian}

Untuk menguji hipotesis tentang pengaruh non-financial performance serta financial performance terhadap nilai perusahaan digunakan analisis regresi

Tabel 1. Statistik Deskriptif berganda. Berikut model persamaan regresi tersebut:

$$
\begin{gathered}
\mathrm{PBV}_{\mathrm{it}}=\alpha_{\mathrm{o}}+\beta_{1} \mathrm{CSR}_{\mathrm{it}}+\beta_{2} \mathrm{ROA}_{\mathrm{it}}+ \\
\beta_{3} \mathrm{CR}_{\mathrm{it}}+\beta_{4} \mathrm{DR}_{\mathrm{it}}+\varepsilon_{\mathrm{it}}
\end{gathered}
$$

\section{HASIL DAN PEMBAHASAN \\ Analisis Statistik Deskriptif}

Analisa statistik deskriptif digunakan untuk memberikan gambaran dan mendeskripsikan data yang ada pada penelitian ini. Analisis yang digunakan dalam penelitian ini meliputi nilai minimum, nilai maksimum, nilai mean (rata-rata) dan standar deviasi. Hasil dari perhitungan statistik deskriptif penelitian ini dapat dilihat pada tabel berikut:

\begin{tabular}{|l|l|r|r|r|r|}
\hline & N & Minimum & Maximum & Mean & \multicolumn{1}{c|}{$\begin{array}{c}\text { Std. } \\
\text { Deviation }\end{array}$} \\
\hline CSR & 110 &, 21 & 1,00 &, 6024 &, 26722 \\
\hline ROA & 110 & 1,49 & 62,09 & 11,8106 & 9,40575 \\
\hline CR & 110 & 36,36 & 691,33 & 222,8642 & 139,54461 \\
\hline DR & 110 & 13,31 & 72,40 & 41,7562 & 15,36361 \\
\hline PBV & 110 &, 38 & 62,93 & 5,0489 & 10,64839 \\
\hline $\begin{array}{l}\text { Valid N } \\
\text { (listwise) }\end{array}$ & 110 & & & & \\
\hline
\end{tabular}

Sumber: data hasil pengolahan IBM SPSS 20, tahun 2017

\section{Analisis Uji Korelasi}

Analisis korelasi digunakan untuk mengetahui kekuatan dan arah hubungan antara dua variabel. Angka korelasi berkisar antara -1 sampai 1. Semakin mendekati 1 maka korelasi mendekati sempurna.
Sementara nilai negatif dan positif mengindikasikan arah hubungan. Arah hubungan yang positif menandakan bahwa pola hubungan searah. Hasil dari perhitungan uji korelasi penelitian ini dapat dilihat pada tabel berikut:

Tabel 2. Hasil Uji Pearson Correlation

\begin{tabular}{|c|l|c|c|c|c|c|}
\hline \multicolumn{2}{|c|}{} & CSR & ROA & CR & DR & PBV \\
\hline \multirow{4}{*}{ CSR } & Pearson Correlation & 1 &, 022 &,- 062 &, 063 &, 043 \\
\cline { 2 - 7 } & Sig. (2-tailed) & &, 822 &, 523 &, 516 &, 652 \\
\cline { 2 - 7 } & N & 110 & 110 & 110 & 110 & 110 \\
\hline \multirow{2}{*}{ ROA } & Pearson Correlation &, 022 & 1 &,- 078 &, 035 &, $671^{* *}$ \\
\cline { 2 - 7 } & Sig. (2-tailed) &, 822 & &, 419 &, 715 &, 000 \\
\hline
\end{tabular}


Jurnal Pendidikan Akuntansi Indonesia, Vol. XVI, No. 1, Tahun 2018

Jovita Marcella \& Wijaya Triwacananingrum

$82-97$

\begin{tabular}{|c|c|c|c|c|c|c|}
\hline & $\mathrm{N}$ & 110 & 110 & 110 & 110 & 110 \\
\hline \multirow{3}{*}{ CR } & Pearson Correlation &,- 062 &,- 078 & 1 &,$- 476^{* *}$ &,$- 228^{*}$ \\
\hline & Sig. (2-tailed) &, 523 & ,419 & & ,000 & 017 \\
\hline & $\mathrm{N}$ & 110 & 110 & 110 & 110 & 110 \\
\hline \multirow{3}{*}{ DR } & Pearson Correlation & 063 & ,035 &,$- 476^{* *}$ & 1 & $340^{* *}$ \\
\hline & Sig. (2-tailed) &, 516 &, 715 & ,000 & & ,000 \\
\hline & $\mathrm{N}$ & 110 & 110 & 110 & 110 & 110 \\
\hline \multirow{3}{*}{ PBV } & Pearson Correlation & ,043 & ,671** &,$- 228^{*}$ &, $340^{* *}$ & 1 \\
\hline & Sig. (2-tailed) & ,652 & , 000 & ,017 & ,000 & \\
\hline & $\mathrm{N}$ & 110 & 110 & 110 & 110 & 110 \\
\hline
\end{tabular}

Sumber: data hasil pengolahan IBM SPSS 20, tahun 2017

Berdasarkan hasil output di atas perhitungan pearson correlation menggunakan data X (CSR, ROA, CR, DR) dan Y (PBV) dapat dijelaskan bahwa hanya korelasi antara CR dan PBV yang bernilai negatif. Artinya korelasi antara CR dan PBV tidak searah. Sedangkan jika dilihat dari perolehan $\mathrm{p}$ hitung, didapatkan bahwa hanya korelasi CSR dan PBV yang tidak signifikan. Hal ini terlihat dari p hitung CSR $0,652>0,05$.

Tabel 3. Hasil Uji Kolmogorov-Smirnov

\begin{tabular}{|l|l|r|}
\hline \multicolumn{2}{|l|}{} & \multicolumn{1}{|c|}{$\begin{array}{c}\text { Unstandardized } \\
\text { Residual }\end{array}$} \\
\hline N & Mean & $0 \mathrm{E}-7$ \\
\hline Normal Parameters & a,b &, 55734449 \\
\cline { 2 - 3 } & $\begin{array}{l}\text { Std. } \\
\text { Deviation }\end{array}$ &, 104 \\
\hline Most Extreme Differences & Absolute &, 104 \\
\cline { 2 - 3 } & Positive &,- 093 \\
\cline { 2 - 3 } & Negative & 1,091 \\
\hline Kolmogorov-Smirnov Z &, 185 \\
\hline Asymp. Sig. (2-tailed) & \\
\hline a. Test distribution is Normal. & \\
\hline b. Calculated from data. & \\
\hline
\end{tabular}

Sumber: data hasil pengolahan IBM SPSS 20, tahun 2017

Tabel di atas memperlihatkan bahwa hasil uji normalitas dengan Kolmogorovsmirnov test menunjukkan bahwa nilai $\mathrm{K}-\mathrm{S}$

\section{Uji Normalitas}

Uji normalitas bertujuan untuk menguji apakah variabel yang terdapat dalam model penelitian ini terdistribusi normal atau tidak. Model penelitian yang baik adalah yang memiliki distribusi data normal atau mendekati normal. Hasil perhitungan normalitas pada penelitian ini dapat dilihat pada gambar dan tabel berikut:

hitung terhadap 110 data sampel penelitian ini adalah sebesar 1,091. Dimana itu berarti nilai K-S hitung 1,091 > K-S tabel 0,1296 
dengan tingkat signifikansi jauh di atas 0,05 yaitu 0,185 . Sehingga dapat diambil kesimpulan bahwa H0 diterima. Residual Uji Multikolinearitas

Tabel 4. Hasil Uji Multikolinearitas terdistribusi secara normal dengan kata lain sampel dalam penelitian ini cukup mewakili populasi.

\begin{tabular}{|c|c|c|c|c|c|c|c|c|}
\hline \multirow{2}{*}{\multicolumn{2}{|c|}{ Model }} & \multicolumn{2}{|c|}{$\begin{array}{l}\text { Unstandardized } \\
\text { Coefficients }\end{array}$} & \multirow{2}{*}{$\begin{array}{c}\begin{array}{c}\text { Standardized } \\
\text { Coefficients }\end{array} \\
\text { Beta }\end{array}$} & \multirow[t]{2}{*}{$\mathbf{t}$} & \multirow[t]{2}{*}{ Sig. } & \multicolumn{2}{|c|}{ Collinearity Statistics } \\
\hline & & B & $\begin{array}{l}\text { Std. } \\
\text { Error }\end{array}$ & & & & Tolerance & VIF \\
\hline \multirow{5}{*}{1} & $\begin{array}{l}\text { (Cons } \\
\text { tant) }\end{array}$ & $-28,136$ & 15,596 & & $-1,804$ & ,074 & & \\
\hline & CSR & 2,778 & 1,746 &, 120 & 1,591 & ,115 & ,979 & 1,021 \\
\hline & ROA & 8,421 & 1,161 & ,566 & 7,251 & ,000 & ,914 & 1,094 \\
\hline & $\mathrm{CR}$ & $-2,120$ & 1,545 &,- 126 & $-1,372$ &, 173 &, 658 & 1,519 \\
\hline & DR & 7,459 & 2,342 & ,297 & 3,185 & ,002 & ,641 & 1,559 \\
\hline
\end{tabular}

Sumber: data hasil pengolahan IBM SPSS 20, tahun 2017

Berdasarkan nilai tolerance dan VIF yang terdapat pada tabel 4.4 dapat disimpulkan bahwa keempat variabel independen (CSR, ROA, CR dan DR) tidak terdapat multikolineraritas, hal ini dikarenakan semua nilai tolerance (TOL) berada di atas 0,1 dan nilai VIF setiap variabel berada di bawah 10 .

\section{Uji Heteroskedastisitas}

Pengujian

heteroskedastisitas penelitian ini dilakukan dengan membuat perhitungan statistik menggunakan uji white sebagai berikut:

Tabel 5. Hasil Uji White

\begin{tabular}{|c|c|c|c|c|}
\hline Model & $\mathbf{R}$ & R Square & $\begin{array}{l}\text { Adjusted R } \\
\text { Square }\end{array}$ & $\begin{array}{l}\text { Std. Error of the } \\
\text { Estimate }\end{array}$ \\
\hline 1 &, $569^{\mathrm{a}}$ & ,324 & ,299 & ,43787 \\
\hline
\end{tabular}

Sumber: data hasil pengolahan IBM SPSS 20, tahun 2017

Berdasarkan hasil output diatas, dapat dilihat bahwa R-Square dari penelitian ini adalah sebesar 0,324. Untuk mendapatkan nilai chi-square hitung, maka R-Square dikalikan dengan total sampel yaitu 110 sehingga mendapatkan nilai chisquare hitung sebesar 35,64.

Setelah mendapatkan nilai chisquare hitung, maka selanjutnya membandingkannya dengan chi-square tabel. Untuk mendapatkan chi-square tabel, terlebih dahulu harus menentukan berapa besarnya degree of freedom (df) dengan menggunakan rumus K-1. Dimana besarnya $\mathrm{K}$ berasal dari jumlah variabel independen dalam penelitian. Sehingga df $=4-1=3$. Dengan demikian didapatkan nilai chisquare tabel sebesar 7,81 (lampiran E). Dasar pengambilan pada uji white ini adalah apabila nilai chi-square tabel lebih besar 
dari nilai chi-square hitung maka terdapat gejala heteroskedastisitas dalam model regresi. Jika sebaliknya maka tidak terjadi. Oleh karena nilai chi-square tabel $<$ chisquare hitung sebesar 7,81 < 35,64 maka dapat disimpulkan bahwa tidak terjadi heteroskedastisitas dalam model regresi penelitian ini.

\section{Uji Signifikansi Simultan (Uji F)}

Uji statistik $F$ pada dasarnya dilakukan untuk menguji apakah semua variabel independen yang dimasukkan dalam model mempunyai pengaruh secara bersama-sama (simultan) terhadap variabel dependennya. Besarnya signifikansi $\alpha$ yang ditetapkan adalah 0,05. Berikut hasil uji $\mathrm{F}$ pada penelitian ini:

Tabel 6. Hasil Uji Statistik F

\begin{tabular}{|c|c|c|c|c|c|c|}
\hline \multicolumn{2}{|c|}{ Model } & Sum of Squares & df & Mean Square & $\mathbf{F}$ & Sig. \\
\hline \multirow{3}{*}{1} & Regression & 46,557 & 4 & 11,639 & 36,095 &, $000^{\mathrm{b}}$ \\
\hline & Residual & 33,859 & 105 & ,322 & & \\
\hline & Total & 80,416 & 109 & & & \\
\hline \multicolumn{7}{|c|}{ a. Dependent Variable: PBV } \\
\hline
\end{tabular}

Sumber: data hasil pengolahan IBM SPSS 20, tahun 2017

Berdasarkan tabel diperoleh nilai $\mathrm{F}$ hitung sebesar 36,095 dengan probabilitas 0,000 . Oleh karena probabilitas jauh lebih kecil daripada $\alpha=0,05$ dan diperkuat dengan nilai $\mathrm{F}$ hitung yang lebih besar daripada $F$ tabel sebesar 36,095 $>2,46$ (lampiran F) maka dapat disimpulkan bahwa koefisien regresi CSR, ROA, CR, DR secara simultan berpengaruh terhadap variabel dependennya yaitu PBV.
Uji Koefisien Determinasi $\left(\mathbf{R}^{2}\right)$

Koefisien determinasi digunakan untuk mengukur seberapa besar pengaruh variabel independen terhadap dependennya. Nilai koefisien determinasi yang mendekati 1 menunjukkan bahwa variabel-variabel independen memberikan hampir semua informasi yang dibutuhkan untuk memprediksi variabel dependen. Hasil dari koefisien determinasi penelitian ini dapat dilihat pada tabel berikut:

Tabel 7. Hasil Uji Koefisien Determinasi

\begin{tabular}{|l|c|c|c|c|}
\hline Model & R & R Square & Adjusted R Square & \multicolumn{2}{c|}{$\begin{array}{c}\text { Std. Error of the } \\
\text { Estimate }\end{array}$} \\
\hline 1 &, $761^{\text {a }}$ &, 579 &, 563 &, 56786 \\
\hline \multicolumn{7}{|l}{ a. Predictors: (Constant), DR, CSR, ROA, CR } \\
\hline \multicolumn{2}{|l}{ b. Dependent Variable: PBV } \\
\hline
\end{tabular}

Sumber: data hasil pengolahan IBM SPSS 20, tahun 2017 
Berdasarkan tampilan output SPSS di atas, menunjukkan besarnya angka $\mathrm{R}$ yaitu hasil nilai koefisien linier korelasi lima variabel (CSR, ROA, CR, DR dan PBV) adalah 0,761 atau $76,1 \%$ memiliki makna bahwa hubungannya yang tinggi karena nilai $\mathrm{R}$ mendekati 1 . Sedangkan adjusted $\mathrm{R}^{2}$ adalah sebesar 0,563 atau $56,3 \%$. Hal ini menunjukkan bahwa persentase sumbangan pengaruh variabel independen pada penelitian ini (CSR, ROA, CR dan DR) terhadap variabel dependennya yaitu nilai perusahaan (PBV) adalah sebesar 56,3\%. Atau dengan kata lain 56,3\% variasi PBV dapat dijelaskan oleh keempat variabel independen CSR, ROA, CR dan DR. Sedangkan sisanya $(100 \%-56,3 \%=43,7 \%)$ dijelaskan oleh variabel diluar model penelitian ini.

\section{Uji Signifikansi Parsial (Uji t)}

Uji statistik $t$ pada dasarnya menunjukkan seberapa jauh pengaruh satu variabel independen secara individual dalam menerangkan variasi variabel dependen. Besarnya nilai signifikansi yang telah ditetapkan adalah $\alpha=0,05$. Hasil uji t pada penelitian ini dapat dilihat pada tabel berikut

Tabel 8. Hasil Uji Statistik t

\begin{tabular}{|c|c|c|c|c|c|c|}
\hline \multirow{2}{*}{\multicolumn{2}{|c|}{ Model }} & \multicolumn{2}{|c|}{$\begin{array}{l}\text { Unstandardized } \\
\text { Coefficients }\end{array}$} & \multirow{2}{*}{$\begin{array}{c}\begin{array}{c}\text { Standardized } \\
\text { Coefficients }\end{array} \\
\text { Beta } \\
\end{array}$} & \multirow[t]{2}{*}{$\mathbf{t}$} & \multirow[t]{2}{*}{ Sig. } \\
\hline & & B & Std. Error & & & \\
\hline \multirow{5}{*}{1} & (Constant) & $-28,136$ & 15,596 & & $-1,804$ & ,074 \\
\hline & CSR & 2,778 & 1,746 &, 120 & 1,591 &, 115 \\
\hline & ROA & 8,421 & 1,161 &, 566 & 7,251 &, 000 \\
\hline & $\mathrm{CR}$ & $-2,120$ & 1,545 &,- 126 & $-1,372$ &, 173 \\
\hline & DR & 7,459 & 2,342 & ,297 & 3,185 &, 002 \\
\hline
\end{tabular}

a. Dependent Variable: PBV

Sumber: data hasil pengolahan IBM SPSS 20, tahun 2017

Dari hasil uji t yang terlihat dalam tabel di atas, maka dapat disimpulkan bahwa CSR dan CR secara parsial tidak berpengaruh signifikan terhadap PBV. Karena nilai signifikan lebih besar dari 0,05. Sedangkan ROA dan DR secara parsial memiliki pengaruh yang signifikan terhadap PBV karena nilai signifikan lebih kecil dari 0,05.

\section{Pembahasan}

Tabel 9. Ringkasan Hasil Hipotesis

\begin{tabular}{|c|c|}
\hline $\begin{array}{c}\text { Nama } \\
\text { Hipotesis }\end{array}$ & $\begin{array}{c}\text { Hasil } \\
\text { Hipotesis }\end{array}$ \\
\hline Hipotesis 1 & $\begin{array}{l}\text { Pengungkapan } \\
\text { memiliki pengaruh positif } \\
\text { namun tidak signifikan } \\
\text { terhadap firm value indeks }\end{array}$ \\
\hline
\end{tabular}

\begin{tabular}{|l|l|}
\hline & $\begin{array}{l}\text { saham LQ 45 yang terdaftar } \\
\text { di BEI periode 2012-2016 }\end{array}$ \\
\hline Hiipotesis 2 & $\begin{array}{l}\text { ROA memiliki pengaruh } \\
\text { positif dan signifikan } \\
\text { terhadap firm value indeks } \\
\text { saham LQ 45 yang terdaftar } \\
\text { di BEI periode 2012-2016 }\end{array}$ \\
\hline Hipotesis 3 & $\begin{array}{l}\text { CR memiliki pengaruh } \\
\text { negatif dan tidak signifikan } \\
\text { terhadap firm value indeks } \\
\text { saham LQ 45 yang terdaftar } \\
\text { di BEI periode 2012-2016 }\end{array}$ \\
\hline Hipotesis 4 & $\begin{array}{l}\text { DR memiliki pengaruh } \\
\text { positif dan signifikan } \\
\text { terhadap firm value indeks } \\
\text { saham LQ 45 yang terdaftar }\end{array}$ \\
\hline
\end{tabular}




\begin{tabular}{|c|c|}
\hline & di BEI periode 2012-2016 \\
\hline Hasil Uji F & $\begin{array}{l}\text { Pengungkapan CSR, ROA, } \\
\text { CR dan DR secara simultan } \\
\text { memiliki pengaruh yang } \\
\text { signifikan terhadap firm } \\
\text { value indeks saham LQ } 45 \\
\text { yang terdaftar di BEI } \\
\text { periode 2012-2016 }\end{array}$ \\
\hline \multicolumn{2}{|c|}{$\begin{array}{l}\text { Sumber: data hasil pengolahan } \\
\text { pengamatan dari output IBM SPSS } \\
\text { tahun } 2017\end{array}$} \\
\hline
\end{tabular}

a. Pengaruh Pengungkapan Corporate Social Responsibility (CSR) terhadap Firm Value.

Hasil penelitian untuk hipotesis pertama menyatakan bahwa berdasarkan hasil analisis menunjukkan nilai signifikan variabel CSR sebesar 0,899 dimana nilai tersebut berada lebih besar dari tingkat signifikansi 0,05 . Artinya bahwa pengungkapan CSR yang telah dilakukan pada perusahaan LQ 45 tidak memiliki pengaruh yang signifikan terhadap nilai perusahaan. Sehingga pengungkapan CSR terbukti belum bisa menjadi salah satu faktor penentu meningkatnya nilai perusahaan. Para investor maupun stakeholders belum memasukkan hal ini menjadi bahan pertimbangan mereka dalam proses pengambilan keputusan untuk berinvestasi. Hasil penelitian ini sesuai dengan Ardimas dan Wardoyo (2014), Ariella (2015), Gusfarini et al (2016) yang menyatakan bahwa pengungkapan CSR tidak memiliki pengaruh yang signifikan terhadap nilai perusahaan. Namun, penelitian ini bertentangan dengan hasil penelitian yang dilakukan Permanasari (2010), William (2012), Putra dan Wirakusuma (2015) yang menyatakan corporate social responsibility terbukti memiliki pengaruh yang signifikan terhadap nilai perusahaan. b. Pengaruh Return On Asset (ROA) terhadap Firm Value.

Hasil penelitian untuk hipotesis kedua menunjukkan nilai signifikan variabel ROA sebesar 0,000 dimana nilai tersebut berada lebih kecil dari tingkat signifikansi 0,05 . Oleh karena itu hasil pengujian menyatakan bahwa return on asset (ROA) memiliki pengaruh signifikan terhadap nilai perusahaan. Hasil penelitian ini sesuai dengan landasan teori Hanafi dan Halim (2012) dalam Stiyarini (2016) yang menyatakan bahwa rasio yang tinggi menunjukkan efisiensi manajemen aset, yang berarti efisiensi manajemen. Bahwa manajemen dapat menggunakan total aktiva perusahaan dengan baik (aktiva lancar dan tetap) untuk memperoleh laba. Hal ini dikarenakan kontribusi peningkatan laba dapat memberikan indikasi bagi investor mengenai kinerja perusahaan. Karena tingkat pengembalian (return) atau deviden akan semakin besar. Keadaan ini akan berdampak pada harga saham perusahaan di pasar modal yang semakin meningkat sehingga berpengaruh juga terhadap peningkatan nilai perusahaan. Dengan demikian hasil pengujian mendukung hipotesis kedua dari penelitian ini, sehingga hipotesis diterima.

Hasil ini didukung oleh penelitian yang dilakukan oleh Susilaningrum (2009), Ardimas dan Wardoyo (2014), Dwipayana dan Suaryana (2016) serta Berthabelly (2016) yang menyatakan bahwa ROA memiliki pengaruh yang signifikan terhadap nilai perusahaan. Karena laba yang tinggi dapat meningkatkan kepercayaan invetor bagi perusahaan tersebut. Sebaliknya, hasil penelitian ini tidak sejalan dengan penelitian yang dilakukan Lumintu (2016), Dewanto et al (2017) dan Munawaroh (2014) 
c. Pengaruh Current Ratio (CR) terhadap Firm Value.

Hasil penelitian untuk hipotesis ketiga menunjukkan nilai signifikan variabel CR sebesar 0,660 dimana nilai tersebut berada lebih besar dari tingkat signifikansi 0,05 . Oleh karena itu hasil pengujian menyatakan bahwa current ratio (CR) tidak memiliki pengaruh signifikan terhadap nilai perusahaan. Dengan kata lain kemampuan perusahaan dalam membayar utang lancar dengan menggunakan aktiva lancar yang dimiliki belum maksimal, yang artinya variabel tersebut tidak mampu digunakan untuk memprediksi nilai perusahaan di masa mendatang. Hasil penelitian ini sesuai dengan teori Hanafi dan Halim (2012) dalam Stiyarini (2016) yang menyatakan bahwa aktiva lancar secara umum menghasilkan return yang lebih rendah dibandingkan dengan aktiva tetap. Karena current ratio lebih berkaitan dengan kondisi internal perusahaan dalam memenuhi kewajiban jangka pendeknya sehingga investor kurang memperhatikan rasio jangka pendek. Investor lebih memperhatikan rasio dalam jangka panjang yang lebih memiliki nilai dalam pengembalian atas investasi atau tingkat return yang tinggi. Dengan demikian hasil pengujian tidak mendukung hipotesis ketiga dari penelitian ini, sehingga hipotesis tidak diterima.

Hasil ini didukung oleh penelitian yang telah dilakukan Gultom et al (2013), Ariella (2015) dan Kusumadewi (2015) yang mengatakan bahwa current ratio tidak memiliki pengaruh signifikan terhadap nilai perusahaan. Akan tetapi, hasil penelitian ini tidak sesuai dengan penelitian yang dilakukan oleh Setiawan dan Pardiman (2014) serta Hasania et al (2016) yang menyimpulkan bahwa current ratio berpengaruh signifikan terhadap nilai perusahaan.

d. Pengaruh Debt Ratio (DR) terhadap Firm Value.

Hasil penelitian untuk hipotesis keempat menunjukkan nilai signifikan variabel DR adalah sebesar 0,000 dimana nilai tersebut berada lebih kecil dari tingkat signifikansi 0,05 . Oleh karena itu hasil pengujian menyatakan bahwa debt ratio (DR) memiliki pengaruh signifikan terhadap nilai perusahaan. Hal ini menandakan bahwa nilai DR masing-masing perusahaan ternyata memberikan sinyal yang kuat sebagai salah satu faktor meningkatnya nilai suatu perusahaan karena apabila dikaitkan dengan hasil perhitungan yang memperlihatkan bahwa selama kurun waktu lima tahun penggunaan hutang dalam indeks saham LQ 45 masih dapat dijamin oleh total aset yang dimiliki masing-masing perusahaan. Hasil pengujian ini juga didukung dengan teori sinyal yang menyatakan bahwa perusahaan yang berkualitas baik akan memberikan sinyal pada pasar dengan demikian pasar diharapkan dapat membedakan perusahaan yang berkualitas baik dan buruk. Hutang memberikan informasi mengenai aktiva dan modal perusahaan. Karena hutang yang tinggi meningkatkan keyakinan akan aktiva dan modal perusahaan. Hal ini menunjukkan bahwa semakin tinggi DR berarti semakun besar jumlah modal yang digunakan sebagai modal investasi. Dengan demikian, hasil pengujian mendukung hipotesis keempat dari penelitian ini, sehingga hipotesis diterima.

Hasil penelitian ini sesuai dengan penelitian sebelumnya yang dilakukan oleh Perdana (2010) dalam Dwipayana dan Suaryana (2016) dan Dewanto et al (2017) yang menyatakan bahwa DR berpengaruh signifikan terhadap nilai perusahaan. Namun, 
penelitian ini bertentangan dengan penelitian yang dilakukan Ariella (2015) dan Barasa (2009) yang menyatakan bahwa debt ratio tidak memiliki pengaruh yang signifikan terhadap nilai perusahaan.

e. Pengaruh Pengungkapan CSR dan Financial Performance secara Simultan terhadap Firm Value.

Berdasarkan hasil uji hipotesis yang telah dilakukan terhadap CSR, ROA, CR dan DR menunjukkan bahwa nilai signifikan $\mathrm{f}$ hitung $(0,000)<\alpha=$ 0,05 . Selain itu hal ini juga diperkuat dengan hasil uji lainnya yang dapat dilihat pada tabel 4.7 yang menunjukkan bahwa keempat variabel bebas tersebut mempunyai kontribusi terhadap nilai perusahaan sebesar $53,5 \%$ sedangkan sisanya sebesar $46,5 \%$ dipengaruhi oleh variabel lain yang tidak diteliti dalam penelitian ini. Dari hasil uji tersebut membuktikan keempat variabel tersebut dapat memberikan pengaruh yang signifikan terhadap nilai perusahaan. Karena ketiganya secara bersamaan dapat mencapai persentase angka diatas $50 \%$. Sehingga dapat disimpulkan bahwa CSR, ROA, CR, dan DR secara bersama-sama mempengaruhi nilai perusahaan.

\section{SIMPULAN DAN SARAN Simpulan}

Penelitian ini dilakukan untuk menguji secara empiris pengaruh nonfinancial performance (CSR) dan financial performance (ROA, CR, DR) baik secara parsial maupun simultan terhadap firm value perusahaan. Berdasarkan hasil olah data serta pembahasan berikut adalah kesimpulan dari penelitian ini:

1. Variabel CSR pada perusahaan LQ 45 periode 2012-2016 memiliki pengaruh yang tidak signifikan terhadap nilai perusahaan. Hal ini mengindikasikan bila investor membeli saham pada perusahaan yang tergolong dalam indeks saham LQ 45, maka mereka tidak akan meletakkan prioritas penilaian pada aspek CSR dalam pengambilan keputusan investasinya.

2. Variabel profitabilitas yang diproksikan dengan return on asset (ROA) memiliki pengaruh yang positif dan signifikan terhadap nilai perusahaan. Hal ini menunjukkan bahwa kondisi kinerja keuangan perusahaan berpengaruh terhadap minat investor dalam berinvestasi pada perusahaan tersebut.

3. Variabel likuiditas yang diproksikan dengan current ratio (CR) memiliki pengaruh yang negatif dan tidak signifikan atau berdampak terhadap nilai perusahaan. Hal ini menunjukkan bahwa investor lebih memperhatikan rasio jangka panjang yang lebih memiliki nilai dalam tingkat return yang tinggi.

4. Variabel leverage yang diproksikan dengan debt ratio (DR) memiliki pengaruh yang positif dan signifikan terhadap nilai perusahaan. Artinya ketika debt ratio meningkat maka nilai perusahaan juga ikut meningkat begitupun sebaliknya.

5. Variabel CSR, profitabilitas, likuiditas dan leverage secara simultan memiliki pengaruh yang signifikan terhadap nilai perusahaan. Artinya kedua faktor nonfinancial (CSR) dan financial performance (ROA, CR, DR) memberikan kontribusi secara bersamaan terhadap besarnya nilai perusahaan.

\section{Saran}

Berdasarkan hasil analisis dan kesimpulan adapun beberapa saran untuk penelitian selanjutnya, sebagai berikut:

1. Sebaiknya penelitian selanjutnya menggunakan variabel selain pengungkapan CSR sebagai faktor nonfinancial performance, misalnya 
kepemilikan manajerial, struktur modal dan ukuran perusahaan.

2. Sebaiknya penelitian selanjutnya menggunakan variabel likuiditas selain current ratio (CR) sebagai faktor financial performance, misalnya quick ratio, cash ratio. Atau dengan menambahkan variabel lainnya seperti Earning per Share.

3. Sebaiknya penelitian selanjutnya menggunakan variabel kontrol atau moderator guna memperkuat hasil penelitian. Misalnya unexpected earning, growth dan size.

\section{DAFTAR PUSTAKA}

Berthabelly, V. (2016). Analisis Pengaruh Kinerja Keuangan dan Good Corporate Governance Terhadap Nilai Perusahaan LQ45 yang Terdaftar di Bursa Efek Indonesia Periode 2012-2014 . Skripsi .

Bursa Efek Indonesia. (2014). Ringkasan Kinerja Perusahaan Tercatat. Dipetik Agustus 2017, dari Indonesia Stock Exchange: http://www.idx.co.id/idid/beranda/publikasi/ringkasankinerj aperusahaantercatat.aspx

Damayanti, \& Giantari, M. (2009). Pengaruh Rasio Keuangan Terhadap Return Saham pada Perusahaan Manufaktur yang Tergabung dalam Indeks LQ 45 di BEI . ISSN 18297978 .

Fauziah , G., Irwanto, A. K., \& Syamsun, M. (2016). Pengaruh Pengungkapan Corporate Social Responsibility Terhadap Nilai Perusahaan pada Indeks Saham LQ 45 . Manajemen IKM, Vol.11 No.1 (52-60). ISSN 2085-8418.
Ghozali, I. (2012). Aplikasi Analisis Multivariate degan Program IBM SPSS 20. Semarang: Badan Penerbit Universitas Diponegoro.

GRI. (2013). G4 Sustainability Reporting Guidelines. Dipetik September 2017, dari Global Reporting Initiatives: https://www.globalreporting.org/stan dards

Harahap, M. E. (2014, Februari 14). TeoriTeori Tentang CSR . Dipetik Agustus 2017, dari Muchtar Effendi Harahap: http://muchtareffendiharahap.blogsp ot.co.id/2014/02/teori-teori-tentangcsr-coorporate.html

Ikatan Akuntansi Indonesia. (2012). Standar Akuntansi Keuangan. Jakarta: Salemba Empat.

Indrawan, D. C. (2011). Pengaruh Corporate Social Responsibility (CSR) Terhadap Kinerja Perusahaan . Jurnal Akuntansi Universitas Diponegoro Semarang .

Kasim, Muslimin, \& Dewanto , A. K. (2017). Pengaruh Rasio Leverage dan Profitabilitas Terhadap Nilai Perusahaan Industri Makanan dan Minuman yang Terdaftar di Bursa Efek Indonesia . Jurnal Umum Ilmu Manajemen Universitas Tadulako Vol.3, No.1, 039-054. ISSN Online 2443-3578 .

Kundiman, A., \& Hakim, L. (2016). Pengaruh Current Ratio, Debt To Equity Ratio, Return On Asset, Return On Equity Terhadap Harga Saham Pada Indeks LQ 45 Di BEI 
Periode 2010-2014. Among Makarti Vol.9 No 18.

Kusumadewi ， A. (2014). Pengaruh Likuiditas dan Profitabilitas Terhadap Hraga Saham Perusahaan Manufaktur yang Terdaftar di Bursa Efek Indonesia Periode 2010-2013. Jurnal Akuntansi, Universitas Dian Nuswantoro Semarang .

Munawaroh, A. (2014). Pengaruh Profitabilitas Terhadap Nilai Perusahaan dengan Corporate Social Responsibility Sebagai Variabel Moderating. Jurnal Ilmu dan Riset Akuntansi Vol 3 No. 4.

Sekaran , U., \& Bougie , R. (2013). Research Methods for Business Sixth Edition. United Kingdom: Wiley .

Stiyarini. (2016 ). Pengaruh Kinerja Keuangan Terhadap Nilai Perusahaan pada Perusahaan Jasa Telekomunikasi . Jurnal Ilmu dan Riset Manajemen: Volume 5, Nomor 2. ISSN: 2461-0593.

Susilaningrum, C. (2016). Pengaruh Return on Asset, Rasio Likuiditas dan Rasio Solvabilitas Terhadap Nilai Perusahaan Dengan Pengungkapan CSR Sebagai Variabel Moderasi . Jurnal Profita Edisi 8 .

Walsh , C. (2004). Key Management: RasioRasio Manajemen Penting Penggerak dan Pengendali Bisnis. Jakarta: Erlangga.

Wardoyo, \& Ardimas , W. (2014). Pengaruh Kinerja Keuangan dan Corporate
Social Responsibility Terhadap Nilai Perusahaan pada Bank Go Public yang Terdaftar di BEI. Benefit Jurnal Manajemen dan Bisnis Volume 18, Nomor 1, 57-66. 